\title{
Improving number sense in kindergarten children with low achievement in mathematics
}

\author{
${ }^{1}$ Universidad de Cádiz. (Spain) \\ ${ }^{2}$ University of New Mexico (USA)
}

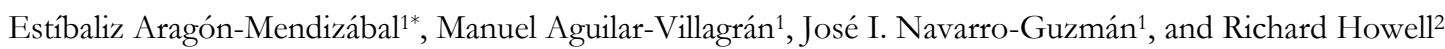

\begin{abstract}
Título: La mejora del sentido de número en niños de preescolar con bajo rendimiento en matemáticas.

Resumen: El presente estudio evaluó la eficacia del programa de intervención educativa denominado Jugando con los números-2 en el aprendizaje matemático temprano. Este software incide en el aprendizaje y el perfeccionamiento de las habilidades de razonamiento matemático utilizando un procedimiento basado en la evidencia. Un total de 156 niños y niñas en edad preescolar (edad media $=65.39$ meses) los cuales fueron evaluados mediante el instrumento Early Numeracy Test (ENT), un test computarizado para evaluar la competencia matemática temprana. Se utilizó un diseño experimental con grupo control y evaluaciones pre y post-intervención. Se obtuvieron diferencias significativas antes y después de la intervención para el grupo experimental mostrando un incremento en las puntuaciones arrojadas que fueron significativamente superiores a las alcanzadas por el grupo control. El tamaño del efecto fue también significativo $(d=1.35$; y $=.56$ ). Esta intervención educativa utilizando como base un programa computarizado no pretende reemplazar la instrucción tradicional, pero puede ayudar a mejorar el rendimiento de los estudiantes jóvenes en riesgo de desarrollar dificultades de aprendizaje de las matemáticas.

Palabras clave: Matemática temprana; bajo rendimiento en matemáticas; educación infantil; intervención basada en ordenadores.
\end{abstract}

\section{Introduction}

Number sense is an emergent construct that is complex to define. Although currently there is no consensus on its conceptualisation and operationalization (Gersten, Jordan, \& Flojo, 2005), number sense can be understood as the capacity to manipulate and understand numbers and arithmetic operations, together with the ability to make arithmetic judgments derived from this understanding, in order to build effective strategies in situations requiring the use of mathematical concepts (Jordan, Kaplan, Nabors Oláh, \& Locuniak, 2006).

Researchers agree that number sense, in the 3 to 6 year old age group, involves a set of skills related to knowledge of numbers and operations, such as: discrimination of small amounts, subitizing, cardinality, comparison of number sizes and processing sets. It is composed of three distinct elements: counting, number knowledge and number operations (Jordan, Glutting, \& Ramineni, 2008).

According to Wilson \& Dehaene (2007), number sense is crucial to the performance of both symbolic and nonsymbolic tasks. People who lack number sense can exhibit developmental deficits in several aspects of mathematics. Dehaene (2001) called this "hypothesis of number sense deficit," and suggested that the origin of developmental dyscalculia was found in such a deficit, which was caused by a structural or functional alteration in the intraparietal sulcus,

* Correspondence address [Dirección para correspondencia]: Dra. Estíbaliz Aragón Mendizábal. Departamento de Psicología. Universidad de Cádiz. Campus Río San Pedro. 11510 Puerto Real, Cádiz (España). E-mail: estivaliz.aragon@uca.es
Abstract: The present study evaluated the effectiveness of educational intervention software, Playing with Numbers- 2 on early mathematics learning. This software trains learning and mathematical reasoning skills, using an evidenced-based procedure. A total of 156 second-year preschool boys and girls (Mean age $=65.39$ months) were assessed by the Early Numeracy Test (ENT), a computerized test to evaluate early math competency. An experimental design with control group and pre and post-intervention assessments was used. Significant differences between pre- and post- intervention for the experimental group was obtained average increase for ENT scores achieved by the experimental group was significantly higher than the control group. The effect size was also significant $(d=1.35$; and $r=.56)$. This educational intervention using computer-based software, while it does not replace face-to-face instruction, may help to improve the performance of young students at risk of developing problems learning mathematics. Key words: Early mathematics; low math achievement; kindergarten; computer-based intervention.

an area of the brain thought to process symbolic numerical information (Dehaene, Piazza, Pinel \& Cohen, 2003; Butterworth, Varma, \& Laurillard, 2011). Number sense is based on the ability to mentally represent and manipulate quantities on a conceptual number line, which may be biologically determined and developed early in life (Dehaene, 2001). This mental number line can be regarded as a foundation on which the acquisition of more advanced mathematical concepts and procedures is built (Schneider, Grabner, \& Paetsch, 2009).

In our area of interest, the importance of number sense lies in its role as a strong predictor of mathematical performance in school (Jordan, Kaplan, Locuniak, \& Ramineni, 2007; Jordan, Kaplan, Ramineni, \& Locuniak, 2009). Similarly, inadequate number sense makes regular instruction in mathematics more difficult (Baroody \& Rosu, 2006). This accentuates the need for early intervention to improve this ability in children who do not show adequate development of number sense.

Research has confirmed the effectiveness of targeted early intervention with pupils at risk of learning difficulties in mathematics (Gervasoni, 2005; Wright, Martland, Stafford, \& Stanger, 2006; Young-Loveridge, 2004). There are programmes for mathematical learning in early education that have shown early mathematical competence (EMC) successfully improving pupils' math skills (Aragón, Aguilar, Navarro, \& Araújo, 2015; Bulut, 2013; Clements \& Sarama, 2011; Griffin, 2004; National Research Council, 2009; Sarama, Clements, Starkey, Klein, \& Wakeley, 2008). And some government initiatives such as the Head Start Programme and Early Head Start Programme, provide a comprehensive edu- 
cation to children in disadvantaged situations (Hindman, Skibbe, Miller, \& Zimmerman, 2010; U.S. Department of Health and Human Services, 2009). Their main goal is to increase proficiency in basic academic skills such as early mathematical competence (Pianta, Belsky, Houts, \& Morrison, 2007). Some results were significant (Hindman et al., 2010; Reynolds, Temple, \& Ou, 2010), although progress tended to dissipate after starting formal schooling (Reynolds, Temple, White, Ou \& Robertson, 2011). The UK Department of Education, in collaboration with Edge Hill University, launched the Every Child Counts (ECC) programme. ECC is a specific programme aimed at developing competencies in those children who have problems in math, with encouraging results (Torgerson et al., 2012). Besides government sponsored programmes and state development efforts, researchers' concerns regarding difficulties in the early years of development have led to the creation of several specific intervention initiatives in mathematics. One promising approach is to construct adaptive computer games based on neuroscience findings to enhance the learning of mathematics. There have been several promising examples: the Number Race (Wilson, Dehaene, Pinel, Revkin, Cohen, \& Cohen, 2006); the Mathematics Recovery Programme (Wright et al., 2006), Graphogame-Maths (Butterworth et al., 2011), and the Numeracy Recovery Programme (Dowker, 2005).

The authors' specific interest is in computer-based programmes that contribute to the acquisition of number sense in the early years. Using the computer as a teaching and learning tool brings significant advantages. For example, it is a valuable tool for assessing the level of pupil competence and analysing the development of the academic skills under study, providing accuracy and consistency that is difficult to achieve using other methods or tools (Butterworth \& Laurillard, 2010; Vernadakis, Giannousi, Derri, Michalopoulos, \& Kioumourtzoglou, 2012).

In general terms, the use of adaptive computer games gives users an educational opportunity which is continuously available, and unrestricted in terms of space, time and support. It can be used to improve skills by adapting to students' needs, and encouraging personalised, individualized learning (Judge, Puckett, \& Cabuk, 2004). This last advantage provides an added benefit for teachers by facilitating learning without continuous supervision by the teacher.

Research suggests that the use of computer assisted instruction increases students' success and the development of thinking skills (Akta-Arnas, 2005; Ayvaci \& Devecioglu 2010; Halpern, Millis, Graesser, Butler, Forsyth, \& Cai, 2012; Saade, Morin, \& Thomas, 2012), as this type of training stimulates processes of active understanding rather than encouraging memorisation strategies (Döst, Saglam, \& Altay, 2011). Similarly, it contributes to improving sensory, emotional and psychomotor capabilities and development (Ayvaci et al., 2010; Vernadakis, Avgerinos, Tsitskari, \& Zachopoulou, 2005). Consequently, research shows positive results supporting computer-assisted instruction as a tool for improving academic skills (Ihmedieh, 2010; Melton, Graf, \& Chopak-Foss, 2009), especially in the area of teaching and learning mathematics (Jansen et al., 2013; Klinkenberg, Straatemeier, \& van der Maas, 2011).

Currently, computer-based training programmes are often used complementary to traditional teaching methods (Irish, 2002). Many authors stress the importance and need for new educational technology programmes to be used in a complementary fashion with other methods of teaching, and not be isolated from other instructional practices (Gee, 2009; Klopfer, Osterweil, \& Salen, 2009). By contrast, there are other positions defending the value and effectiveness of stand-alone computer assisted instruction, regarding it as more effective than traditional teaching (Demir \& Kabaday1, 2008). Some of the most representative programmes, which have contributed to the improvement of number sense are: Number Worlds (Griffin, 2000), Number Race (Wilson et al., 2006), and Building Blocks (Clements \& Sarama, 2007). Since new education technologies are widely available, some efforts have been made to validate this learning procedure in order to provide educators more reliable instructional tools.

In this study the goal was to validate the effectiveness of a software programme called, "Playing with Numbers 2.0," (1) which focuses on teaching number sense at early ages, specifically for 5-6 year old children. Specifically, the main research question was to investigate if a specific remedial program in mathematics using specialized computer software was effective for pre-primary school students with low math achievement, compared to other students with equivalent or higher performance in math but following a standard curriculum in mathematics.

\section{Method}

\section{Participants}

A sample of students was recruited from four preschool and primary schools in a geographic region encompassing a mid-sized and a smaller city in Spain. Two of the schools were grant-aided and the other two were public schools, all having a "middle class" socio-economic profile. The participants were 156 pupils in their last year of Preschool Education, ages ranged from 59 to 72 months $(M=65.39$; $S D=$ 3.52). Of the total sample, 81 participants were girls, ages ranged from 59 to 72 months $(M=65.51 ; S D=3.6)$, and 75 were boys, whose ages ranged between 59 and 71 months ( $M=65.26 ; S D=3.45)$. Participants were selected based on their mathematical competence assessed by the ENT-R according to the values expressed in Table 1 . Students diagnosed with special educational needs were excluded. Parents gave informed written consent for their child's participation. 


\section{Instruments}

(1).- Playing with Numbers 2.0, (Navarro, Ruiz, Alcalde, Aguilar, \& Marchena, 2007). ${ }^{1}$

The computerized training programme "Playing with Numbers 2.0," consists of seven groups of activities including classification, comparison, simple arithmetic problems, distribution, size discrimination, seriation and a set of tasks aimed at the mastery of the number line. The tasks performed in this programme are considered to be essential for developing number sense in young children, and is based on arithmetic domain-specific predictors model Dehaene, (2001), Desoete, Ceulemans, De Weerdt, \& Pieters, (2012), and remedial programs by Toll \& Van Luit (2014). "Playing with Numbers 2.0," software was created using Adobe Flash Professional, and uses Shockwave Flash files (SWF) that correspond to basic Internet standards. Vector graphic applications were used, so that the small size of the files would permit direct use on the Internet, as well as the possibility for the software to be used on a variety of hardware (i.e., PDAs, tablets, whiteboards, etc.) without a reduction in the quality of the graphics.

"Playing with Numbers 2.0," includes activities for the development, learning, and reinforcement of mathematical thinking skills. It is designed for students in the first year of primary education, however its ability to adjust for differing levels of difficulty means it can be used with younger children, or with those with special educational needs. It attempts to contribute to the logical-mathematical development of pupils, in an accessible and motivating way. The "Playing with Numbers 2.0," activities are described below.

\section{Classification tasks}

Through classification tasks students internalize the ability to classify objects, as well as the ability to differentiate between individual objects and groups of objects (Figure 1). It has three difficulty levels and each level contains three activities. The difference between levels is in the number of cubes presented and their distribution on the screen.

\section{Addition and Subtraction Problem Solving}

The aim of this set of activities is to introduce students to basic problem solving. It is based on easy arithmetic facts and uses a part-whole concept to perform the addition and subtraction operations. Static problems are presented in two different ways. At the first level, parts are presented and the programme requests an answer about the whole. At second level, the programme requests an answer about a part in based on the whole and the other part (Figure 2).

\footnotetext{
1 "Playing with Numbers" software received the Educative Tools Award from Andalusian Society of Mathematical Education "THALES".
}

\section{$C L \triangle$ SIFIC $R$} Nivel 2

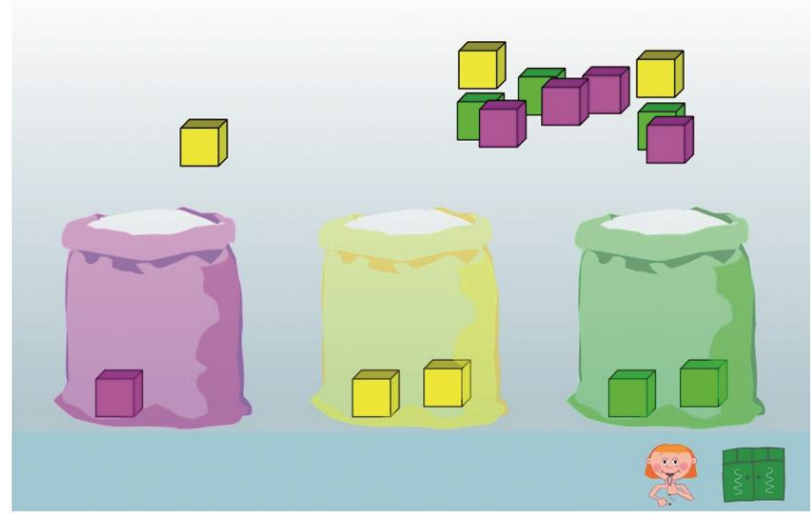

Figure 1. Example of "Classification tasks". Students collected objects by a feature (colour).

COMBINACIONES

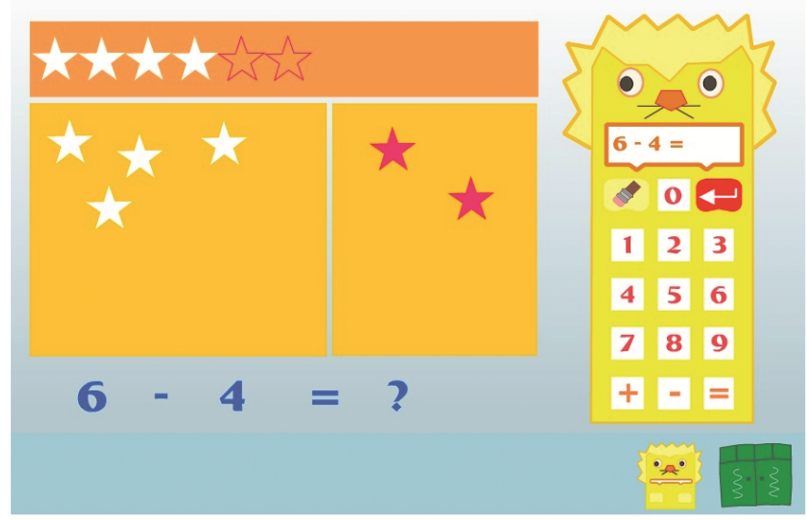

Figure 2. Example of "Addition and Subtraction Problem Solving".

\section{Comparisons tasks}

Through this group of activities students discover the differences and similarities between two or more settings. The programme presents activities to discriminate and differentiate objects compared to a model. Comparison activities contain two difficulty levels, with twelve questions in each level.

\section{Distribution tasks}

The main objective of this activity is to teach the ability to distribute objects into equal groups. The problems presented consist of distributing objects with the requirement that each group has the same number of objects. The difficulty of the task increases as the number of subjects and objects are increased.

\section{Discrimination tasks}

The principal objective of discrimination tasks is to demonstrate the difference between the cardinal value of a number and physical size of its representation. This group of 
tasks presents twelve items each with different levels of complexity based on the numbers for comparison (Figure 3). At the first level of difficulty, a one-digit-number is presented for contrast; in the second- and third-levels, students must compare two numbers of two-or-three-digits in length.

DI/CRIM\|NAR

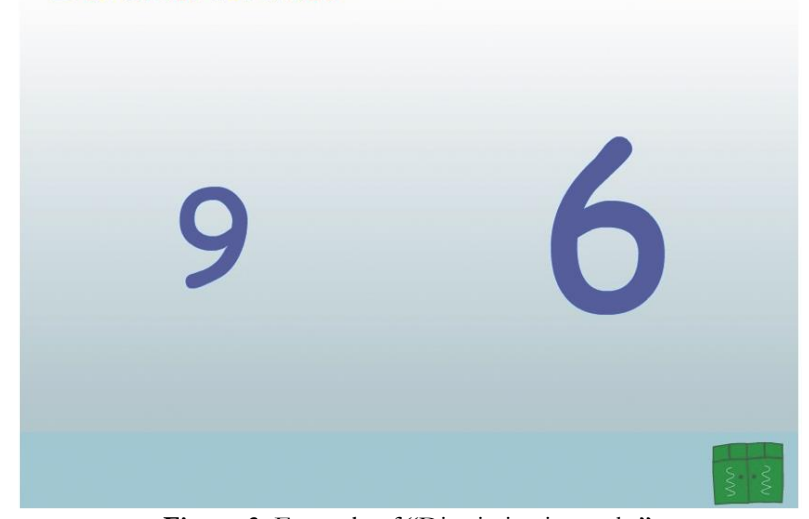

Figure 3. Example of "Discrimination tasks".

Nivel 2

Seriation tasks. These activities refer to the ability to sort objects according to a given characteristic, such as size, colour, shape, or type. There are several difficulty levels, designed to order groups of objects (order 1) or groups of numbers from 0 to 9 (order 2), and 10 to 20 (order 3 ). In this activity, students have to choose one of four options in which objects or numbers are ordered from lowest to highest or in reverse order as specified by the instructions.

Number line tasks. The purpose of these tasks is to improve counting ability. There are four levels of difficulty, with ten tasks in each level. Students have to point to a number on a visual number line (Figure 4). Difficulty increases according to the magnitude of the numbers presented. At the highest level (number line level 4), complexity increases because numbers are not presented on the number line and students are required to count correctly or use estimation strategies to find the correct answer.

\section{RECTA NUMÉRICA}

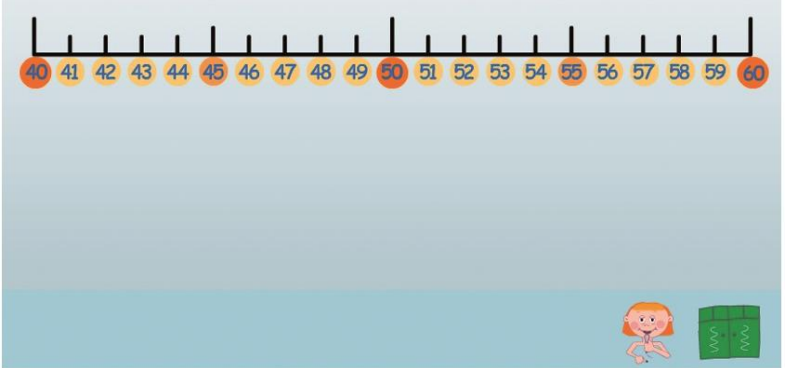

Figure 4. Example of "Number line tasks".
The software provides feedback in two conditions: (1) if the user's response is correct, a reinforcing sound is delivered. (2) if the user's response is not correct, a noise is provided by the computer and then the correct response is delivered by the software. Within each task, explicit examples of instruction are clarified by teachers who have an active role, guiding and stimulating the student's performance.

(2).- Early Numeracy Test Revised (ENT- R) (Van Luit et al., 2015).

The ENT-R is a task-oriented test that is designed to measure the level of early mathematical competence. Using ENT-R, the teacher can establish how a child, or the whole class of children, master number sense. By comparing the performance of one child with that of a normative group of children, the level of early mathematical competence can be determined. The test consists of a total of nine components (four are relational and five numerical), all of which have been found to be important for children in kindergarten and first grade of primary school: comparing, linking quantities, one to one correspondence, arranging, using numerals, synchronous and shortened counting, resultative counting, applying knowledge of numbers and estimating. ENT-R psychometric characteristics allow establishing differences between relational and numerical components, revealing a good internal consistency (Toll \& Van Luit, 2014). The ENT-R includes three parallel versions (A, B and C) of 45 items each. The ENT-R is designed to be administered individually. A computerized version of ENT- $\mathrm{R}$ was used in this study with a Cronbach's alpha of .92 for test items.

\section{Procedure}

A research design using experimental and control groups with pre- post-test intervention measurements was implemented. First, the ENT-R version (A) was individually administered. Assessment sessions lasted between 30 and 45 minutes per student. Then, students were assigned to either experimental or control groups according to ENT-R (A) scores (Table 1). Children in experimental groups 1 and 2, and control group 1 were considered to be "low math achievers," and children in control group 2 were considered to be "typical or normal achievers," according to the standard rules for ENT-R. The reason why the control groups were distributed into two (low and high math achievers) was because the main research question studied the effect of the remedial program on mathematics achieving either for low or high performance students following the school's mainstream math curriculum. 
Table 1. Experimental and Control group's scores on the Early Numeracy Test-Revised (version A).

\begin{tabular}{llcc}
\hline & & \multicolumn{2}{c}{ ENT-R (A) total score (out of 45) } \\
\cline { 3 - 4 } Groups & $n$ & Minimun & Maximun \\
\hline Experimental-1 & 24 & 6 & 13 \\
Experimental-2 & 24 & 14 & 19 \\
Control-1 & 40 & 14 & 19 \\
Control-2 & 68 & 20 & 40 \\
\hline
\end{tabular}

After this assessment, the intervention programme was administrated using the computer programme, "Playing with numbers 2.0," Students were taken from the regular classroom to an adjoining room in groups of 6 , with at least two supervisors/researchers per session. At the beginning of the intervention sessions, children received instruction from computer characters about how to play the game. Each participant received a total of 35 intervention sessions, of approx- imately 30-35 minutes each, 3 sessions per week (an average total of 1050-1250 minutes of instruction). After intervention, a post-test early math competence assessment was administered using the ENT-R, version (B).

\section{Results}

A pretest and posttest descriptive analysis for all groups was calculated. Both experimental and control groups improved their overall performance on the ENT-R, including the total score and subtests (table 2) after intervention. In addition, the gains obtained by the experimental groups in their total test scores were higher than those of the control groups after intervention.

Table 2. Early Numeracy Test-R total score. Descriptive statistics in pre-test and post-test for Experimental and Control groups, and measurement of the gains.

\begin{tabular}{|c|c|c|c|c|c|c|c|c|}
\hline & \multirow[b]{3}{*}{$n$} & \multicolumn{2}{|c|}{ Relational Subtest } & \multicolumn{2}{|c|}{ Numerical Subtest } & \multicolumn{2}{|c|}{ Total ENT-R Score } & \multirow[b]{3}{*}{ Total gains } \\
\hline & & Pre-test & Post-test & Pre-test & Post-test & Pre-test & Post-test & \\
\hline & & $M(s d)$ & $M(s d)$ & $M(s d)$ & $M(s d)$ & $M(s d)$ & $M(s d)$ & \\
\hline \multirow{2}{*}{ Experimental-1 } & \multirow{2}{*}{24} & 7.13 & 13.13 & 3.92 & 10.92 & 11.04 & 24.04 & \multirow{2}{*}{13.00} \\
\hline & & 1.67 & 2.17 & 1.84 & 2.71 & 1.80 & 4.38 & \\
\hline \multirow{2}{*}{ Experimental-2 } & \multirow{2}{*}{24} & 10.13 & 14.54 & 5.75 & 13.50 & 15.88 & 28.04 & \multirow{2}{*}{12.16} \\
\hline & & 2.25 & 1.95 & 2.15 & 3.86 & 1.45 & 4.95 & \\
\hline \multirow{2}{*}{ Control-1 } & \multirow{2}{*}{40} & 9.95 & 11.23 & 6.80 & 10.63 & 16.75 & 21.85 & \multirow{2}{*}{5.1} \\
\hline & & 1.92 & 2.32 & 2.04 & 2.86 & 1.66 & 4.13 & \\
\hline \multirow{2}{*}{ Control-2 } & \multirow{2}{*}{68} & 12.93 & 13.26 & 11.68 & 14.31 & 24.60 & 27.57 & \multirow{2}{*}{2.97} \\
\hline & & 2.17 & 2.35 & 3.53 & 3.46 & 4.19 & 4.74 & \\
\hline \multirow{2}{*}{ Total } & \multirow{2}{*}{156} & 10.84 & 12.92 & 8.32 & 12.72 & 19.16 & 25.63 & \multirow{2}{*}{6.47} \\
\hline & & 2.91 & 2.49 & 4.14 & 3.66 & 5.95 & 5.21 & \\
\hline
\end{tabular}

The differences in gains were significant between Experimental Group 1 and Control Groups 1 and 2 on the total test and subtest scores in favour of the experimental groups. The same results were obtained for Experimental Group 2. In addition, no significant differences were found between Experimental Groups 1 and 2, although pupils who per- formed worst in the pre-test (Experimental Group 1) obtained higher increases in their total test scores and on the relational subtest, but not on the numerical subtest. Finally, no significant differences in gains between Control Groups 1 and 2 were found, but those who performed above average (Experimental Group 2) showed higher gains (table 3).

Table 3. Post hoc comparisons for gains in total test and subtests after intervention between Experimental-1, Experimental-2, Control-1 and Control-2 groups.

\begin{tabular}{|c|c|c|c|c|}
\hline \multirow[b]{2}{*}{ (1) } & \multirow[b]{2}{*}{ (J) } & \multicolumn{3}{|c|}{ Difference between means $(I-J)$} \\
\hline & & $\begin{array}{l}\text { Total } \\
\text { Gains }\end{array}$ & $\begin{array}{c}\text { Relational } \\
\text { Gains }\end{array}$ & $\begin{array}{c}\text { Numerical } \\
\text { Gains }\end{array}$ \\
\hline \multirow[t]{3}{*}{ Experimental-1 } & Control-2 & $10.02 *$ & $5.66^{*}$ & $4.36^{*}$ \\
\hline & Control-1 & $7.90^{*}$ & $4.73^{*}$ & $3.17 *$ \\
\hline & Experimental-2 & .83 & 1.58 & -.75 \\
\hline \multirow[t]{3}{*}{ Experimental-2 } & Experimental-1 & -.83 & -1.58 & .75 \\
\hline & Control-2 & $9.19 *$ & $4.07 *$ & $5.12^{*}$ \\
\hline & Control-1 & $7.06^{*}$ & $3.14^{*}$ & $3.92 *$ \\
\hline \multirow[t]{3}{*}{$\overline{\text { Control-1 }}$} & Experimental-1 & $-7.90^{*}$ & $-4.73^{*}$ & $-3.17 *$ \\
\hline & Control-2 & 2.12 & .93 & 1.19 \\
\hline & Experimental-2 & $-7.06^{*}$ & $-3.14^{*}$ & $-3.92 *$ \\
\hline \multirow[t]{3}{*}{ Control-2 } & Experimental-1 & $-10.02^{*}$ & $-5.66^{*}$ & $-4.36^{*}$ \\
\hline & Control-1 & -2.12 & -.93 & -1.19 \\
\hline & Experimental-2 & $-9.19 *$ & $-4.07 *$ & $-5.12^{*}$ \\
\hline
\end{tabular}

$(*) p<.05$ 
The differences between groups before and after intervention were also investigated. To calculate such differences, the Wilcoxon test was used based on the differences in absolute value of the scores per each condition (pre-test and post-test). The differences were significant in all groups: Experimental-1 $(z=-4.29 ; p<.05)$, Experimental-2 $(z=-4.29$; $p<.05)$, Control-1 $(z=-5.29 ; p<.05)$, and Control-2 $(z=-$ $5.80 ; p<.05)$. These results were expected not only because of the intervention effect but also because of developmental and regular schooling effects.

On the other hand, in order to determine the effect size of the intervention, the results for Experimental Group 2 in the post intervention phase, and those achieved by the matched control group (Control Group 1) were calculated. Both groups were equivalent before the intervention and, therefore, their mean differences were not statistically significant. Cohen's d and Pearson's correlation coefficient were computed $(d=1.35$; and $r=.56)$. According to the post hoc contrasts calculated, pupils who were at risk of math learning difficulties (Experimental Group 1) were equivalent to the group that was below average without intervention (Control group 1). In addition, significant differences for Experimental Group 2 and Control Group 2 were found. Scoring differences were reduced after intervention (Table 4).

Table 4. Post hoc comparisons between Experimental-1, Experimental-2, Control-1 and Control-2 groups for difference between means in total score for pre-test and post-test.

\begin{tabular}{llcc}
\hline \multirow{2}{*}{ (I) } & & \multicolumn{2}{c}{ Difference between means $(I-J)$} \\
\cline { 2 - 4 } Experimental-1 & Control-2 & Pretest & Posttest \\
& Control-1 & $-13.561^{*}$ & $-3.532^{*}$ \\
& Experimental-2 & $-5.708^{*}$ & 2.192 \\
\hline Experimental-2 & Experimental-1 & $4.833^{*}$ & $-4.000^{*}$ \\
& Control-2 & $-8.723^{*}$ & $4.000^{*}$ \\
& Control-1 & -.875 & .468 \\
\hline Control-1 & Experimental-1 & $5.708^{*}$ & $-2.192^{*}$ \\
\hline & Control-2 & $-7.853^{*}$ & $-5.724^{*}$ \\
& Experimental-2 & .875 & $-6.192^{*}$ \\
\hline Control-2 & Experimental-1 & $13.561^{*}$ & $3.532^{*}$ \\
& Control-1 & $7.853^{*}$ & $5.724^{*}$ \\
& Experimental-2 & $8.728^{*}$ & -.468 \\
\hline
\end{tabular}

$(*) p<.05$

\section{Discussion}

This investigation was designed to study if a specific remedial program in mathematics using computer-based software was effective for pre-primary school students who were low math achievers, compared with other students having equivalent or higher performance in math, but following a standard curriculum in mathematics. The relationship between low achievement in early math and its connection to later developing number skills is still to be discovered. However, two main approaches to the question of the development of early math skills have been proposed. One approach stresses the importance of logical thinking, which usually involves the development in preschool children of skills such as: conservation-of-numbers, classifying, correspondence and seriation (Piaget \& Szeminska, 1941). The second approach emphasizes the role of counting skills (Dehaene, 2009). These two approaches were used in designing the computer software used in this intervention. Results from pre and post testing showed improvement on several tasks, suggesting that the remediation was successful in producing an improvement in basic number sense.

Children were required to solve both Piagetian (relational) as well as counting tasks. As the child progressed, the software introduced items involving more difficult tasks. The progressive amount of training produced improved performance in early math skills. Children in the experimental groups compared with the control groups improved significantly in all the computer-based tasks. Both experimental groups achieved higher effect sizes compared with the control groups, suggesting that the programme taught students how to successfully solve the Piagetian as well as the numerical tasks. The benefit of the software was substantial, especially in students who started with lower mathematical performance. However, long-term maintenance of the benefits remains to be evaluated. The results are in line with those studies that advocate the use of computer-based instruction programmes (Ihmedieh, 2010; Melton et al., 2009). In Räsänen et al. (2009) students played two computers games (The Number Race and Graphogame-Math). The Number Race game emphasized numerical comparison and was designed to train number sense. And Graphogame-Math emphasized small sets of exact number sets by training the matching of verbal labels to visual patterns and number symbols. Both interventions improved children's skills in number comparison, compared to a group of typically performing children. Wilson et al. (2006) using just an experimental group, found that five weeks training with The Number Race game improved number comparison, subitizing and subtraction.

One disadvantage of having typically performing children as a control group (2) to a group of lower performing children are the large differences in the students' starting levels. An attempt was made to statistically control for these effects in this study by using gain scores. Thus, more confidence can be posited that the significant findings are due to training effects and not misrepresented by general differences between the groups (Räsänen et al., 2009). Significant intervention effects were found for both experimental groups, increasing scores on the ENT-R (B) after intervention, with large effect size. These finding are consistent with earlier work showing that computer games have a positive effect on number sense in low achieving performers (Wilson, Dehaene, Dubois, \& Fayol, 2009).

Klopfer et al., (2009), and Gee (2009) proposed implementation of this type of instruction as a complement to traditional teaching methods, using it as an additional tool to decrease differences between pupils. In this way, it would be 
possible to facilitate the transition from preschool to primary education and reduce the risk of math learning difficulties in later schooling.

This discussion suggests a critical question for future studies: whether improvement in number sense generalizes to higher-level mathematical tasks in later schooling (Aragón, Navarro, Aguilar, \& Cerda, 2015; Wilson, Revkin, Cohen, Cohen, \& Dehaene, 2006). If the remediation of a number sense deficit is produced, how can children at risk of learning math difficulties take advantage of this procedure? In the area of mathematics, several studies have shown that number sense in the kindergarten years predicts later performance in mathematics (Navarro, Aguilar, García, Menacho, Marchena, \& Alcalde, 2010). Earlier studies also suggest that training number sense can produce long-term

\section{References}

Aktaş-Arnas, Y. (2005). Computer-Assisted Instruction in Pre-School Education. Eurasian Journal of Educational Research, 20, 36-47.

Aragón, E., Aguilar, M., Navarro, J., \& Araújo, A. (2015). Efectos de la aplicación de un programa de entrenamiento específico para el aprendizaje matemático temprano en educación infantil. Revista Española de Pedagogía, 260, 99-113.

Aragón, E., Navarro, J. I., Aguilar, M., \& Cerda, G. (2015). Cognitive predictors of 5-year-old students' early number sense. Journal of Psychodidactics, 20(1), 83-97. doi:10.1387/RevPsicodidact.11088

Ayvaci, H. S., \& Devecioglu, Y. (2010). Computer-assisted instruction to teach concepts in pre-school education. Procedia Social and Behavioral Sciences, 2, 2083-2087. doi:10.1016/j.sbspro.2010.03.285

Baroody, A. J. \& Rosu, L. (2006). Adaptive expertise with basic addition and subtraction combinations - The number sense view. Paper presented at the Meeting of the American Educational Research Association, San Francisco, CA.

Bulut, S. (2013). Desarrollo de la inteligencia en niños en edad preescolar con desventajas socioeconómicas. Anales De Psicología / Annals of Psychology, 29(3), 855-864. doi:10.6018/analesps.29.3.168101

Butterworth, B., \& Laurillard, D. (2010). Low numeracy and dyscalculia: identification and intervention. ZDM Mathematics Education, 42, 527539. doi:10.1007/s11858-010-0267-4

Butterworth, B., Varma, S., \& Laurillard, D. (2011). Dyscalculia: from brain to education. Science, 332(6033), 1049-1053. doi: 10.1126/science.1201536

Clements, D. H., \& Sarama, J. (2007). Building blocks, Volumes 1 and 2. Columbus, OH: McGraw Hill Education.

Clements, D. H., \& Sarama, J. (2011). Early childhood mathematics intervention. Science, 333(6045), 968-970. doi:10.1126/science.1204537

Dehaene, S. (2001). Precis of the number sense. Mind \& Language, 16, 16-36. doi:10.1111/1468-0017.00154

Dehaene, S. (2009), Origins of mathematical intuitions. Annals of the New York Academy of Sciences, 1156,232-259. doi: 10.1111/j.17496632.2009.04469.x

Dehaene, S., Piazza, M., Pinel, P., \& Cohen, L. (2003). Three parietal circuits for number processing. Cognitive Neuropsychology, 20, 487-506. doi:10.1080/02643290244000239

Demir, N. \& Kabaday1, A. (2008). Comparison of Traditional and Computer -Assisted Teaching Methods for Preschoolers' Color Concept Acquisition. International Journal of Human Sciences. 5 (1) 1-18

Desoete, A., Ceulemans, A., De Weerdt, F., \& Pieters, S. (2012). Can we predict mathematical learning disabilities from symbolic and non-symbolic comparison tasks in kindergarten? Findings from a longitudinal study. British Journal of Educational Psychology, 82 (1), 64-81.

Döst, S., Saglam, Y., \& Ugur Altay, A. (2011). Use of computer algebra systems in mathematics teaching at university: a teaching experiment. $H$. U. Journal of Education, 40, 140-151 positive effects on mathematical abilities (Griffin, Case, \& Capodilupo, 1995).

The findings support the purpose of this study, which was to determine whether the use of the software programme, "Playing with Numbers 2.0," resulted in improvements in number sense. However, these results should be considered a first step in a series of studies required to prove the overall efficacy of the software in educational practice. Furthermore, much work remains to be done regarding whether basic training on number sense results in transference to other mathematical tasks, over what time period this happens, and whether there is a critical developmental period during which training has the most effect.

Acknowledgments.- This study was founded by PSI2015-63856-P (MINECO/FEDER) project.

Dowker, A. D. (2005). Individual differences in arithmetic. Implications for psychology, neuroscience and education. Hove, UK: Psychology Press.

Gee, J. P. (2009). Deep learning properties of good digital games: how far can they go? In U. Ritterfeld, M. Cody, \& P. Vorderer (Eds.), Serious games: Mechanisms and effects (pp. 65-80). New York \& London: Routledge.

Gersten, R., Jordan, N. C., \& Flojo, J. R. (2005). Early identification and interventions for students with mathematics difficulties. Journal of Learning Disabilities, 38, 293-304. doi:10.1177/00222194050380040301

Gervasoni, A. (2005). The diverse learning needs of young children who were selected for an intervention program. In H. L. Chick y J. L. Vincent (Eds.), Proceedings of the 29th annual conference of the International Group for the Psychology of Mathematics Education (Vol. 3, pp. 33-40). Melbourne, Australia: PME.

Griffin, S. (2000). Number Worlds: Preschool level. Durham, NH: Number Worlds Alliance Inc.

Griffin, S. (2004). Building number sense with Number Worlds: A mathematics program for young children. Early Childhood Research Quarterly, 19, 173-180. doi:10.1016/j.ecresq.2004.01.012

Griffin, S., Case, R., \& Capodilupo, A. (1995). Teaching for understanding: The importance of central conceptual structures in the elementary mathematics curriculum. In A. McKeough, I. Lupert, \& A. Marini (Eds.), Teaching for transfer: Fostering generalization in learning (pp. 121-151). Hillsdale, NJ: Erlbaum.

Halpern, D. F., Millis, K., Graesser, A. C., Butler, H., Forsyth, C., \& Cai, Z. (2012). Operation ARA: A computerized learning game that teaches critical thinking and scientific reasoning. Thinking Skills and Creativity, 7, 93-100.

Hindman, A. H., Skibbe, L. E., Miller, A., \& Zimmerman, M. (2010). Ecological contexts and early learning: Contributions of child, family, and classroom factors during Head Start, to literacy and mathematics growth through first grade. Early Childhood Research Quarterly, 25, 235250. doi:10.1016/j.ecresq.2009.11.003

Ihmedieh, F. (2010). The role of computer technology in teaching reading and writing: Early childhood teachers' beliefs and practices. Journal of Research in Childhood Education, 24(1), 60-79. doi:10.1080/02568540903439409

Irish, C. (2002). Using peg- and keyword mnemonics and computer-assisted instruction to enhance basic multiplication performance in elementary students with learning and cognitive disabilities. Journal of Special Education Technology, 17(4), 29-40.

Jansen, B. R. J., Louwerse, J., Straatemeier, M., Van der Ven, S. H. G., Klinkenberg, S., \& Van der Maas, H. L. J. (2013).The influence of experiencing success in math on math anxiety, perceived math competence, and math performance. Learning and Individual Differences, 24, 190-197

Jordan, N. C., Glutting, J., \& Ramineni, C. (2008). A number sense assessment tool for identifying children at risk for mathematical difficulties. 
In A. Dowker (Ed.), Mathematical difficulties: Psychology and intervention (pp. 45-58). San Diego, CA: Academic Press. http://dx.doi.org/10.1016/B978-012373629-1.50005-8

Jordan, N. C., Kaplan, D., Locuniak, M. N., \& Ramineni, C. (2007). Predicting first-grade math achievement from developmental number sense trajectories. Learning Disabilities Research \& Practice, 22(1), 36-46. doi:10.1111/j.1540-5826.2007.00229.x

Jordan, N. C., Kaplan, D., Nabors Oláh, L. \& Locuniak, M. N. (2006), Number sense growth in kindergarten: A longitudinal investigation of children at risk for mathematics difficulties. Cbild Development, 77, 153175. doi: $10.1111 / j .1467-8624.2006 .00862 . x$

Jordan, N. C., Kaplan, D., Ramineni, C., \& Locuniak, M. N. (2009). Early math matters: Kindergarten number competence and later mathematics outcomes. Developmental Psychology, 45(3), 850-867. doi:10.1037/a0014939

Judge, S., Puckett, K., \& Cabuk, B. (2004). Digital equity: New findings from the early childhood longitudinal study. Journal of Research on Technology in Education, 36(4), 383-396.

Klinkenberg, S., Straatemeier, M., \& van der Maas, H. L. J. (2011). Computer adaptive practice of maths ability using a new item response model for on the fly ability and difficulty estimation. Computers in Education, 57, 1813-1824. doi:10.1016/j.compedu.2011.02.003.

Klopfer, E., Osterweil, S., \& Salen, K. (2009). Moving learning games forward: Obstacles, opportunities, \& openness. Boston: The Education Arcade, Retrieved November 5, 2012, from http://education.mit.edu/papers/MovingLearningGamesForward_Ed Arcade.pdf.

Melton, B., Graf, H., \& Chopak-Foss, J. (2009). Achievement and satisfaction in blended learning versus traditional general health course designs. International Journal for the Scholarship of Teaching and Learning, 3(1), 1-13.

National Research Council (2009). Mathematics learning in early childhood: Paths toward excellence and equity. Washington, DC: The National Academies Press.

Navarro, J. I., Aguilar, M., García, M., Menacho, I., Marchena, E., \& Alcalde, C. (2010). Diferencias en habilidades matemáticas tempranas en niños y niñas de 4 a 8 años. Revista Española de Pedagogía, 68, 85-98.

Navarro, J. I., Ruiz, G., Alcalde, C., Aguilar, M. \& Marchena, E. (2007). Jugando con los números 2. Software educativo. Cádiz: Departamento de Psicología.

Piaget, J., \& Szeminska, A. (1941). Génesis del número en el niño. Buenos Aires: Guadalupe.

Pianta, R. C., Belsky, J., Houts, R., \& Morrison, F. (2007). Opportunities to learn in America's elementary classrooms. Science, 315, 1795-1976. doi:10.1126/science.1139719

Räsänen, P., Salminen, J., Wilson, A. J., Aunio, P., \& Dehaene, S. (2009). Computer-assisted intervention for children with low numeracy skills. $\begin{array}{lll}\text { Cognitive } & \text { Development, } & \text { 24(4), }\end{array}$ http://dx.doi.org/10.1016/i.cogdev.2009.09.003

Reynolds, A. J., Temple, J. A., White, B. A. B., Ou, S., \& Robertson, D. L. (2011). Age 26 cost- benefit analysis of the child-parent center early education program. Child Development, 82, 379-404. doi:10.1111/j.14678624.2010.01563.x

Reynolds, A., Temple, J. A., \& Ou, S. R. (2010). Preschool education, educational attainment, and crime prevention: Contributions of cognitive and non-cognitive skills. Children and Youth Service Review, 32, 1054-1063. doi:10.1016/j.childyouth.2009.10.019

Saade, R. G., Morin, D., \& Thomas, J. D. (2012). Critical thinking in Elearning environments. Computers in Human Behavior, 28(5), 1608-1617.
Sarama, J., Clements, D. H., Starkey, P., Klein, A., \& Wakeley, A. (2008). Scaling up the implementation of a pre-kindergarten mathematics curriculum: Teaching for understanding with trajectories and technologies. Journal of Research on Educational Effectiveness, 1, 89-119. doi:10.1080/19345740801941332

Schneider, M., Grabner, R. H., \& Paetsch, J. (2009). Mental number line, number line estimation, and mathematical achievement: Their interrelations in grades 5 and 6. Journal of Educational Psychology, 101(2), 359-372. doi:10.1037/a0013840

Toll, S. W., \& Van Luit, J. E. (2014). Effects of remedial numeracy instruction throughout kindergarten starting at different ages: Evidence from a large-scale longitudinal study. Learning and Instruction, 33, 39-49.

Torgerson, C. J., Wiggins, A., (...) \& Tymms, P. (2012). The effectiveness of an intensive individual tutoring programme (Numbers Count) delivered individually or to small groups of children: a randomized controlled trial. Effective Education, 4(1), 73. doi:86. 10.1080/19415532.2013.778591

U.S. Department of Health and Human Services. (2009). Head Start State Col laboration Offices 2007 Annual State Profiles. Retrieved December, 1, 2012, from

http://eclkc.ohs.acf.hhs.gov/hslc/states/collaboration/HSSCO/HSSC O_2007_Profiles1[1].pdf

Van Luit, J., Van De Rijt, B., Araújo, A., Aguilar, M., Aragón, E., Ruiz, G., ...García-Sedeño, M. (2015). Test de evaluación de la competencia matemática temprana-revisado (TEMT-i). Madrid: EOS (en prensa)

Vernadakis, N., Avgerinos, A., Tsitskari, E., \& Zachopoulou, E. (2005). The use of computer assisted instruction in preschool education: making teaching meaningful. Early Childhood Education Journal, 33, 2, 99-104. doi:10.1007/s10643-005-0026-2

Vernadakis, N., Giannousi, M., Derri, V., Michalopoulos, M., \& Kioumourtzoglou, E. (2012). The impact of blended and traditional instruction in students' performance. Procedia Technology, 1, 439-443. doi:10.1016/i.protcy.2012.02.098

Wilson, A. J., Dehaene, S., Dubois, O., \& Fayol, M. (2009). Effects of an adaptive game intervention on accessing number sense in low-socioeconomic-status kindergarten children. Mind, Brain, and Education, 3(4), 224-234.

Wilson, A. J., Dehaene, S., Pinel, P., Revkin, S. K., Cohen, L., \& Cohen, D. (2006). Principles underlying the design of "The Number Race", an adaptive computer game for remediation of dyscalculia. Behavioral and Brain Functions, 2(19).

Wilson, A. J., Revkin, S. K., Cohen, D., Cohen, L., \& Dehaene, S. (2006). An open trial assessment of "The Number Race", an adaptive computer game for remediation of dyscalculia. Behavioral and Brain Functions, 2(20), doi:10.1186/1744-9081-2-20.

Wilson, A.J., \& Dehaene, S. (2007). Number Sense and Developmental Dyscalculia. In D. Coch, G. Dawson and K.W. Fischer (Ed.), Human behavior, learning, and the developing brain: Atypical development (pp. 212-238). New York: Guilford Press.

Wright, R. J., Martland, J., Stafford, A. K., \& Stanger, G. (2006). Teaching number: Advancing children's skills and strategies. London: Paul Chapman Publishing.

Young-Loveridge, J. (2004). Effects on early numeracy of a program using number books and games. Early Childhood Research Quarterly, 19, 82-98. doi:10.1016/j.ecresq.2004.01.001

(Article received: 13-10-2015; revised: 17-12-2015; accepted: 09-01-2016) 